\title{
Students as Partners: Reflections on a Conceptual Model
}

Followed by Student Response by Lianne van Dam

\begin{abstract}
This article reflects on a conceptual model for mapping the work that fits under the broad heading of students as partners in learning and teaching in higher education (Healey, Flint, \& Harrington, 2014). We examine the nature and purpose of the model with reference to specific examples, and reflect on the potential and actual uses of the model in the development of practice and policy, focussing particularly on students as co-inquirers in SoTL. The article also provides a framework for the other articles in a special section of Teaching \& Learning Inquiry on students as co-inquirers.
\end{abstract}

\section{KEYWORDS}

students as partners, partnership learning communities, co-inquiring, co-developing, scholarship of teaching and learning

\section{INTRODUCTION}

Students as partners is a "hot" topic internationally, and most higher education (HE) conferences of the last few years have involved some discussion of the concept. This discussion has been fuelled by a series of publications, mostly from the UK, the US, and Australia which explicitly discuss the concept (Werder \& Otis, 2010; Dunne \& Zandstra, 2011; Little, 2011; NUS, 2012; Solomonides, Reid, \& Petocz, 2012; Dunne \& Owen, 2013; Nygaard, Brand, Bartholomew, \& Millard, 2013; Bryson, 2014; Cook-Sather, Bovill, \& Felten, 2014; HE Academy, 2015). Engaging students as partners is a powerful idea, the implementation of which has the potential to transform HE. Cook-Sather, Bovill, and Felten (2014), for example, highlight that benefits for students and faculty engaging in learning and teaching partnerships are similar and include increased engagement with learning and enhancement activities, transformed thinking about teaching and learning, and developed awareness of one's own role and agency in the wider academic learning community. Recent research indicates that pedagogic approaches that foster partnership lead to supportive learning relationships and employability benefits for students through the development of generic and subject-specific skills and attributes (Crawford, Horsley, Hagyard, \& Derricot, 2015; Pauli, Raymond-Barker, \& Worrell, 2016). Arguably, aspects of partnership have been around much longer in terms of faculty and students co-researching and students undertaking peer-learning, but the language of partnership has not been as explicit in the literature on these topics (e.g., Healey \& Jenkins, 2009; Gärdebo \& Wiggberg, 2012).

Learning and working in partnership has also been proposed as a pedagogically sound alternative to consumerist models of $\mathrm{HE}$, and a constructive response to (inter)national policy drivers emphasizing the importance of student engagement and teaching quality for the transformation of HE fit for a contemporary world. To that end, many institutions and practitioners are working to embed processes of partnership with and between students throughout HE practice 
and policy. Students may be engaged through partnership in various ways including institutional governance, quality assurance, research strategies, community engagement, and extra-curricular activities. H ere we explore one aspect of the students as partners' discussion: that of engaging students as partners in learning and teaching in HE. Our model provides an overarching conceptualisation for this area of practice and policy development, and we invite readers of subsequent papers in this special section to consider how useful a framing this conceptual model provides.

\section{THE CONCEPTUAL MODEL}

This paper reflects on the nature, purpose and possible uses of a conceptual model for thinking about student engagement, focused on engagement through partnership (Healey, Flint, \& Harrington, 2014). The outer ring of the model (Fig. 1) represents the idea that partnership comes under the broader concept of student engagement. We recognise that there are qualitatively different forms of student engagement and not all involve partnership; our focus is on when institutions go beyond listening to the student voice and engage students as co-learners, co-researchers, coinquirers, co-developers, and co-designers. Partnership is a specific form of student engagement, with very high levels of active student participation. Partnership is a way of doing things, rather than an outcome in itself.

Our model distinguishes four overlapping areas in which students can be partners in learning and teaching, from some of which, such as curriculum design, students have traditionally been excluded. This includes partnerships between faculty and students, and pedagogic and professional practices that foster partnerships among students.

Fig. 1. Students as partners in learning and teaching in HE (Source: HE Academy [2015] adapted from Healey et al. [2014, p. 25])

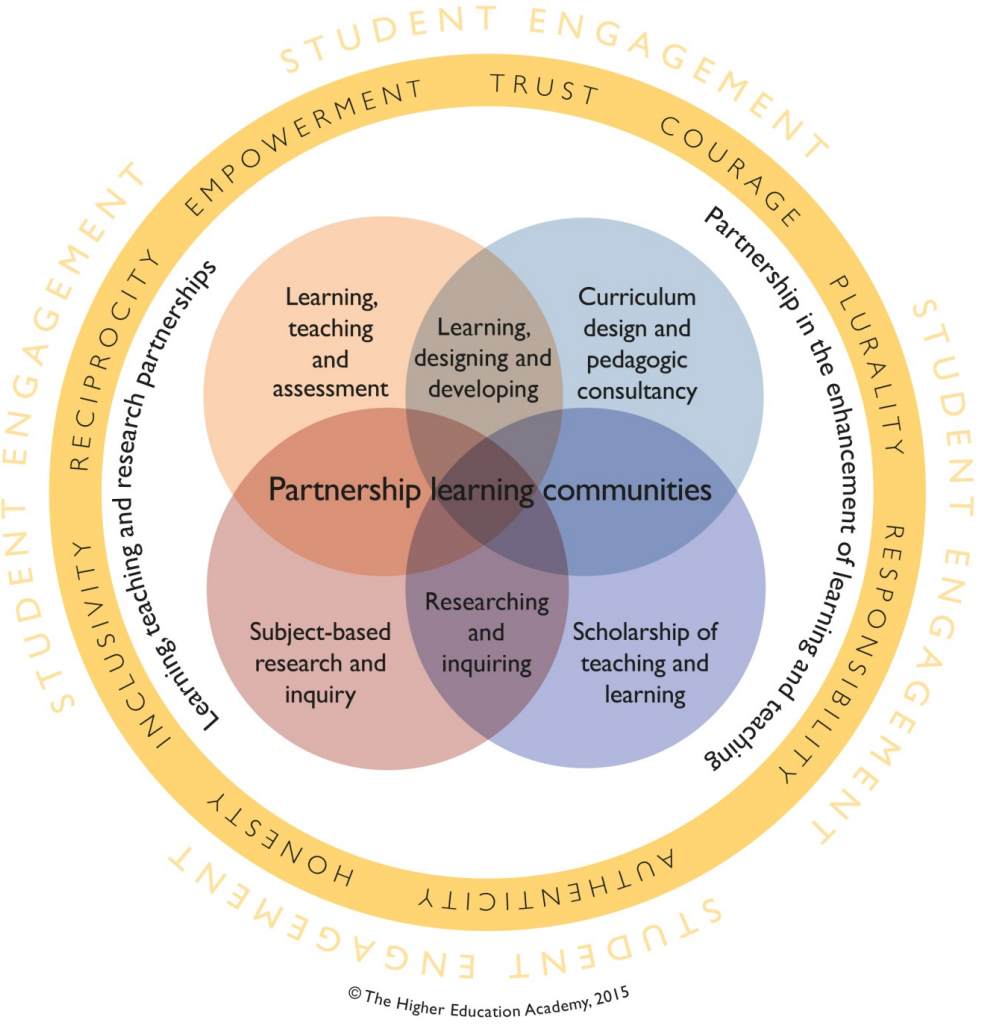

A detailed explanation of the model is available in Healey et al. (2014). The model is not intended as a simple recipe or checklist for partnership, rather a lens through which to explore and 
develop practice, and to provide a common language for dialogue. Others have proposed different models and frameworks, for example, focussing on the role of students as teachers, scholars, and change agents (Healey, Bovill, \& Jenkins, 2015), and looking at wider student engagement (sparqs, 2012). Our conceptual model complements and can be used in conjunction with these to enable evaluation of the desirability and scope for developing partnership practice and policy across different areas of learning and teaching. It can, for example, be used to take stock of one's current context, identify gaps and priorities, and evaluate readiness for change in partnership practice, policy, or strategy. The model can be applied across the range of levels at which partnership may operate; including course, program, department, institution, state and(inter)national levels, and may involve single and multiple disciplines, and interdisciplinary groupings, in the same initiative. Used in conjunction with the companion publication, Framework for Student Engagement through Partnership (HE Academy, 2015), the model can initiate discussion about partnership and facilitate co-development of shared values. It can also underpin exploration of how to embody such values in working and learning arrangements, attitudes, and behaviours within the real, diverse and often constraining contexts of contemporary HE.

A key contribution of the model is to identify four overlapping ways in which students may be engaged in partnership activities within learning and teaching. In particular, it brings together two literatures, which up until now have been largely separate-i.e., engaging students in learning, teaching and research and engaging students in quality enhancement as change agents. Here, we present each of the four areas of the model and examine brief examples where institutions are beginning to embed these practices strategically.

\section{Learning, teaching, and assessment}

Engaging students actively in their learning is the most common form of partnership. Only where students are given a significant amount of autonomy, independence, and choice can this be considered partnership. "High impact" learning experiences in terms of retention and depth of learning (Kuh, 2009) and generating student engagement (Evans, Muijs, \& Tomlinson, 2015) are characterised by active and experiential learning. The Participation and Community Engagement (PACE) units, which are available in almost all undergraduate programs at Macquarie University (n.d.) in Australia, provide a good example. Results from a questionnaire survey of psychology undergraduates at two UK institutions support the hypothesis that students as partners' experience has an effect on graduate attributes and employability (Pauli et al., 2016).

Peer-learning and peer-assessment are effective ways of engaging students and enabling them to take on some of the roles of the teacher. A growing number of departments and universities have peer-assisted learning arrangements in which senior students mentor junior students. Peerassisted learning developed from supplemental instruction, which began at the University of Missouri in 1973. The benefits of this experience are discussed in Clampitt, Park, and Vaughn (this collection). In the Department of Psychology, University of Stirling, selected final year students teach statistics to second year students (Healey, 2016).

Peer and self-assessment are also growing in importance as they are recognised as an essential part of balanced assessment. Peer feedback on formative assessment is central to assessment for learning and is often used to redistribute group marks between individuals (Healey \& Addis, 2004).

\section{Subject-based research and inquiry}

Engaging undergraduates in subject-based research is the most common way in which students experience co-inquiry (Bell, this collection). In many cases these are for selected students and take place outside the curriculum; for example, undertaking research in a laboratory during the 
summer vacation. To mainstream undergraduate research, it needs to be embedded in the curriculum by including learning through inquiry (Healey \& Jenkins, 2009). Half of the high impact activities identified by Kuh (2009) involve students undertaking research and inquiry of various kinds. The more autonomy the students have in these activities, the more likely they are to experience partnership.

However, there are fewer examples of embedding undergraduate research and inquiry across whole institutions (Jenkins \& Healey, 2015). Initiatives such as student as producer at the University of Lincoln, UK (Neary, 2014); students as scholars at Miami University, US (Hodge, Nadler, Shore, \& Taylor, 2011); and project-based learning at Roskilde (Siig Andersen, Wulf-Andersen, \& Heilesen, 2015) are exceptions. In contrast, there are numerous examples of students as partners in research and inquiry at individual course and, to a lesser extent, program levels (Healey \& Jenkins, 2009).

\section{Scholarship of teaching and learning (SoTL)}

Students are usually the subjects of SoTL research rather than the investigators, but an increasing number of instances of them acting as inquirers are being published (e.g., Little, 2011; Werder \& Otis, 2010). In some programs, students may undertake final year SoTL projects as an alternative to more traditional subject-based projects (Healey, 2016). Some institutions have developed strategic institutional initiatives, such as students as academic partners at Birmingham City University, UK (Nygaard, Brand, Bartholomew, \& Millard, 2013) and the Undergraduate Learning and Teaching Internship course at the University of Western Australia (Sandover, Partridge, Dunne, \& Burkill, 2012). One of the earliest of these was the 'students as change agents' initiative at the University of Exeter (Dunne \& Zandstra, 2011). Students from across the university undertook research projects into their teaching and learning environment and, at least in the first few years, made recommendations for enhancement at a university conference attended by senior management. Importantly, this approach sees all parties as having a role throughout the change process, right through to "the development and implementation of new ideas and the co-creation of learning and teaching futures" (Flint, 2015). For other examples see the institution-wide initiatives at Western Washington University and North Carolina AT \& T (Werder et al., this issue).

\section{Curriculum design and pedagogic consultancy}

This is perhaps the area where engagement through partnership is least well developed. Although there are isolated examples, such as students developing open educational resources for subsequent cohorts of students taking their course (Healey, 2016), there are fewer strategic institutional initiatives. A digital literacy program run by students for faculty exists at Oxford Brookes University (2013), UK; while Bryn Mawr College, US, has long-standing provision where students act as pedagogical consultants (Cook-Sather et al., 2014). A discussion of how faculty and student consultants transform themselves through collaboration at Bryn Mawr appears later in this issue (Cook-Sather \& Abbot), while another contribution presents an analysis of engaging students in an educational professional development program (Kandiko Howson \& Weller).

A well-embedded example occurs at the Centre for Sustainable Development, Uppsala University and the Swedish University of Agricultural Sciences, where students have designed and commissioned courses since 1998 (Stoddard et al., 2013). Most of the institutional Change Academy programs run by the HE Academy and Leadership Foundation for HE insisted that teams include at least one student, and HE Academy (2013) thematic programmes exploring students as partners required half of each team to comprise students or their representatives. An example of working in partnership with students over the development of an institutional teaching and learning strategy is discussed in Healey, Mason, O'Connor, and Broadfoot (2010). 
Although we have discussed the nature of students as partners under four headings, many of the examples given have aspects which fall under more than one heading; hence, the overlapping circles in the model. Integrated learning and teaching partnerships are likely to grow in importance as institutions develop their own strategies for engaging students. For example, University College London is developing a connected curriculum initiative that engages students as researchers and change agents and gives students opportunities to act as partners in all four areas identified in the model (Box 1).

Box 1. Students are involved in research-based education and as change agents at University College London (UCL), UK

At University College London, our top strategic priority for the next 20 years is to close the divide between teaching and research. We want to integrate research into every stage of an undergraduate degree, moving from research-led to research-based teaching.

Michael Arthur, president and provost, 30 April 2014: 22

UCL are developing a 'Connected Curriculum' initiative, as the means by which in five years all undergraduate programmes of study will have a profile of 'research-based' characteristics. Research-based education is the focus of UCL's initiative. The connected curriculum has six dimensions based around the core principle of learning through research and inquiry (Fig. 2).

Fig. 2. UCL's Connected Curriculum framework (Source: Fung [2015])

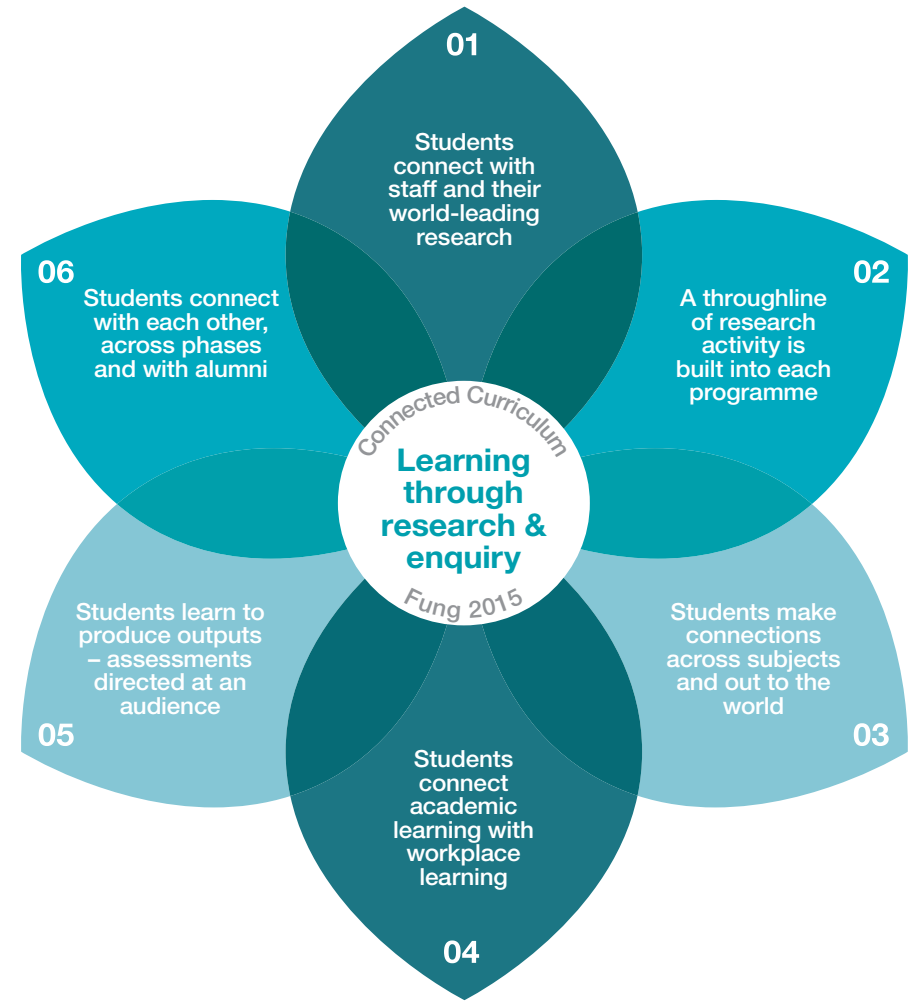

The initiative, which is co-ordinated by the Centre for Advancing Learning and Teaching (CALT), requires changing the criteria for promotion, so that excellence in education is as significant to advancement as excellence in research and innovation. The implementation also 


\section{Fig. 2. UCL's Connected Curriculum framework (Continued)}

involves reviewing all programmes and designing clear strategies for working more closely with students, who can act as partners and change agents. A guide is being developed which presents four benchmark descriptors (a-d) for each of the six Connected Curriculum dimensions: $a$ ) Beginning, b) Developing, c) Developed, and d) Outstanding. This will help departments map their progress in implementing the connected curriculum in taught programmes.

UCL students and staff also have the opportunity to engage as 'ChangeMakers.' The initiative supports students and staff working in partnership on educational enhancement projects. Since the pilot year, when 10 groups of students proposed and led projects of importance to them, the scheme has grown rapidly. In 2015-16 more than 50 student-led and staff-led projects were funded by CALT. Criteria for funding include "a clear strategy for working in partnership with students to address one or more of the Connected Curriculum dimensions" (Fung, 2016). All projects emphasise engagement of students as change agents to enhance the quality of education they receive. There are two strands to the initiative:

- projects, which can be initiated by anyone within the UCL community

- scholars, who are students working with their department to enhance an aspect of the educational experience decided upon by UCL (currently assessment and feedback).

For further information see: Arthur (2014); Fung (2015, 2016);

http://www.ucl.ac.uk/teaching-learning/strategic priorities/connected-curriculum; http://www.ucl.ac.uk/teaching-learning/connected-curriculum/CC_Guide;

https://www.ucl.ac.uk/changemakers.

\section{DEVELOPMENT OF PARTNERSHIP LEARNING COMMUNITIES}

The notion of partnership learning communities, at the centre of the model (Fig. 1), draws attention to the importance of the processes by which partnership operates across the four areas. If partnership is to extend beyond individual projects and initiatives, it makes sense to approach this holistically, with an eye on institutional culture and ethos. Research indicates that fostering a sense of community and belonging increases student retention and success (Thomas, 2012), and we believe developing partnership learning communities among faculty and students can strengthen and sustain engagement.

The concept of partnership learning communities draws on existing models of community which focus on social learning: learning communities and communities of practice (see discussion in Healey, et al., 2014). Whilst there are examples of learning communities and communities of practice that involve faculty and students, their roles within these communities vary. For example, faculty may be positioned in a co-ordination or control role (Tinto, 2003) and students as neophytes in existing faculty-owned communities (Lea, 2005). Application of the communities of practice literature to staff student partnerships is provided by Matthews, Marquis and Healey (2016) in the context of international collaborative writing groups, and Flint and O'Hara (2013) in the context of engaging student representatives with quality enhancement.

Partnership provides a useful lens through which to re-consider these models of community and to explore how new academic communities could be co-created, with all parties contributing to direction and development. We suggest that partnership learning communities are fostered through structures and processes that support partnership relationships, members of the community developing shared values and enacting these through attitudes and behaviour (Healey et al., 2014). The HE Academy's (2015) Framework for Student Engagement through Partnership suggests nine scholarly informed values as a useful starting point: authenticity, inclusivity, honesty, reciprocity, 
empowerment, trust, courage, plurality, and, responsibility. It may be useful for those exploring the development of partnership learning communities to reflect upon the extent to which these values are important to, and enacted through, current activities.

\section{IMPLICATIONS OF THE MODEL FOR SOTL}

While recognising that the definition of SoTL remains a contentious area 25 years after Boyer (Fanghanel, McGowan, Parker, McConnell, Potter, Locke, \& Healey, 2016), our model can be used to reflect honestly and openly on the different motivations, rationales, roles, and potential rewards for students and faculty who may wish to conduct pedagogic research in partnership. It can be used to enable participatory and whole-system approaches to the development of learning, teaching and research strategies, as well as lead to practical outcomes of fostering and embedding partnerships in practice within the wider academic culture. Finally, but arguably most importantly, use of the model provides an opportunity to confront and consider reasons why partnership in learning and teaching may be experienced as unsettling, resisted, and difficult to implement, or in other cases to develop thoughtful understandings as to why partnership might not be a desirable way of working.

Whilst use of the model to facilitate ways of working in partnership in the SoTL process is relatively new, there are examples of practice in this area. One of the most ambitious is in a Teaching and Learning Institute in Canada, which employs approximately 70 students to work on educational projects (Box 2). Alongside learning from existing partnership practice in SoTL, we encourage reflection on ways that more developed practice in other areas of the conceptual model could be used to inspire new work in the SoTL field. For example, could the experience of working with students as co-inquirers in subject-based inquiry be transferred and adapted to co-inquiry in SoTL? How might we learn from experiences of peer assessment processes, as well as principles of authentic assessment, in thinking about partnership in the production of SoTL outputs? Could we apply ideas and processes from experiences of peer mentoring and peer-assisted learning to sustaining SoTL partnership learning communities? As SoTL is an emerging area of partnership in learning and teaching, it is perhaps particularly open to cross-fertilization from other areas and the development of new and creative approaches in partnership with students.

\section{Box 2. Engaging students as full partners at the McMaster Institute for Innovation and Excellence in Teaching and Learning (MIIETL),} Canada

MIIETL (now renamed the Paul R. MacPherson Institute for Leadership, Innovation and Excellence in Teaching) is highly unusual among centres of learning and teaching, in that it puts students explicitly at the heart of its vision, and in the number of students engaged in its activities. MIIETL identifies five main foci:

1. Pedagogy / Educational Development

2. Technology Enhanced Learning

3. Research in Teaching and Learning

4. Program Enhancement

5. Student Engagement

Student engagement is different from the other four main pillars that define MIIETL, in that it permeates the other areas with students being involved as full partners on projects across the board. Student centrality is the first of three guiding principles, alongside evidence-based practice and collaboration, which characterize MIIETL's work:

Students are more than the beneficiaries of MIIETL's work in advancing teaching and 


\section{Box 2. Engaging students as full partners at MIIETL (Continued)}

learning and McMaster. They are core partners who are involved not at the margins of MIIETL's efforts, but at the heart, at a level and with expectations that surpass those of normal student engagement programs. (MIIETL, 2015, p. 8)

Approximately 70 undergraduate and graduate students were engaged as student partners in the mission and work of MIIETL in 2015-16 in ways both central to the processes of the Institute and meaningful to the students. The plan is to explore increasing this to up to 100 students per year. They are employed on average for 5-10 hours a week for one, two, or three semesters, though some continue with projects for longer durations.

Four goals are identified in the Strategy for this aspect of MIIETL's work:

1. Build capacity for the meaningful engagement of student partners in MIIETL's work in educational development, technology, research and advocacy.

2. Identify teaching and learning projects led by student partners who are first authors, presenters, designers and educational leaders.

3. Engage student partners as active collaborators in core aspects of MIIETL operations.

4. Support student advocacy for teaching and learning issues on campus, regionally, nationally and internationally.

Early evaluation of the experience of the pilot of this initiative, involving 13 students from one interdisciplinary programme working in MIIETL, concluded that "the process of developing student-staff partnerships can be troublesome and uncertain, but ultimately transformative in some cases at least" (Marquis et al. 2016, 11). A major outcome is that a significant number of co-authored staff and student publications $(5+)$ and conference presentations $(28+)$ were accepted in the first 30 months of the program. Many more are expected as the outcomes of the expanded program are written-up. For further information see: MIIETL (2015) and Marquis et al (2016).

\section{TENSIONS AND POSSIBILITIES}

We acknowledge that partnership may not be possible, or indeed appropriate, in all learning and teaching contexts (Healey et al., 2014). For example, in curriculum development, appropriate levels of partnership are likely to depend upon the context, the level of study, the relative experience levels and attitudes of the students and the faculty, the subject matter, and the level of influence of professional bodies over the curriculum (Bovill, 2013). Many examples of partnership working and learning cross boundaries between traditional student and faculty roles, casting partners as colearners, colleagues, and co-inquirers; this can be challenging for existing student and faculty identities and practices. It brings to the fore tensions around inclusivity and scale, the power dynamics and ethics of learning relationships, reward and recognition, and transition and sustainability. However, partnership is part of the picture of increasing the active engagement of all members of university communities in their own learning and development, and in the creation of engaging learning and teaching practice and policy. These tensions are not barriers to the development of partnership, but areas where considered and critical attention can create levers for change. Exploring partnership, and addressing these tensions openly, creates new spaces for collaborative and constructive dialogue about teaching and learning.

We see the main function of the model as stimulating conversations about students as partners, and offering faculty and students a language with which to situate their practices and policies. The model is relatively new, and as such we are still learning about its use and impact. 
However, we are aware that in recent months the model has begun to be used by several individuals and organisations. For example, Matthews has used it to frame her Australian Office for Learning and Teaching (OLT) National Teaching Fellowship on Students as Partners and the International Summer Institute on Students as Partners has used it as the structure for the workshops that Felten and Matthews delivered with their student partners. Moreover, the OLT in Australia has used it in their Transforming Practice Programme on Student Engagement: Students as Partners.

Within the UK, elements of the HE Academy (2015) framework, incorporating the adapted conceptual model, have been used within HE Academy change and strategic enhancement programmes which involved 37 institutional teams working on partnership practice and policy initiatives. Similarly, the model has informed discourse at the institutional and national level, as a framing for learning and teaching conferences (e.g., the University of Chichester in 2015) and the work of sector agencies (e.g., The Student Engagement Partnership, 2014).

\section{FUTURE DEVELOPMENT AND RESEARCH}

Students as partners is a rapidly growing area of interest in higher education. One indication of this is the launch of a specialist journal in the field-International Journal for Students as Partners. No doubt our thinking about appropriate conceptual models will evolve as policies and practices continue to be developed in this area. However, the reviews, responses to the many presentations we have made, and the use of our model as a framework for pedagogic initiatives and programs in the two years since we first developed it, suggest that the four overlapping areas of interest, along with the central focus on partnership learning communities, provide a useful classification of the students as partners' literature. The model gives proponents of students as partners a language with which to explore the territory and has opened up discussions comparing the nature of the four areas and the challenges faced in implementing policies and practices and developing the associated partnership learning communities. By bringing together two previously largely separate literatures on students as partners in learning, teaching and research (left hand side of the model), and partnership in the enhancement of the quality of learning and teaching (right hand side), the model is already beginning to pay dividends in terms of new insights into the similarities and differences in the two literatures and the potential of transferring ideas between them. Excitingly, we are beginning to see some strategic well-embedded institutional initiatives emerging, which are integrating policies and practices across all four partnership areas identified in the model, such as at UCL (Box 1).

Among the many questions that have arisen, in part, from discussions about the model, we think three in particular deserve attention at this time:

1. How do the policies and practices for developing partnership across the four areas compare and integrate in institutions and how are institutional cultures developing a shared language for partnership?

2. What are the challenges, opportunities and benefits in developing partnership learning communities?

3. What strategies are effective for wide-scale implementation and embedding of students as partners across higher education institutions?

For each of these questions it will be critical to investigate how the answers vary in different national, institutional and disciplinary contexts.

\section{CONCLUSION}

Students as partners is a concept and practice whose time has come. Co-creating, coproducing, co-learning, co-designing, co-developing, co-researching, and co-inquiring involve sharing power and an openness to new ways of working and learning together and, hence, challenges traditional models of $\mathrm{HE}$ relationships. In this paper, we have examined a conceptual model of 
partnership based on four overlapping areas integrated through the process of partnership learning communities. Our model brings together literatures which have often been treated separately and in doing so gives faculty and students a language to talk about where their activities fit and how the values of learning partnerships may operate in their context. Much research remains to be done into what works in which contexts and to theorise the different ways in which partnerships may take place. Though we have concentrated on students as partners in learning and teaching, many of the ideas and principles are applicable to other forms of partnership in HE, including students and faculty working with employers, professional bodies, and community organisations. There are emerging opportunities for those faculty, students, and administrators already engaging through partnership to build on existing good practice and play leading roles in developing policies to spread partnership practice widely within our countries and internationally. If we are serious about the potentially substantial benefits of partnership, we need to explore how these opportunities can be made available to all.

\section{ACKNOWLEDGEMENTS}

The model arises from work commissioned by the UK HE Academy. The views of the authors are their own and do not necessarily reflect those of any organisation. We would like to thank Beth Marquis (McMaster) and Kelly Matthews (Queensland) for helpful comments on an earlier version of this article.

Mick Healey is a HE Consultant and Researcher, Howden (UK); Emeritus Professor, University of Gloucestershire, Cheltenham (UK); Visiting Professor University College London (UK); The Humbodlt Distinguished Scholar in ResearchBased Learning McMaster University (Canada); Adjunct Professor, Macquarie University, Sydney (Australia); Visiting Fellow University of Queensland (Australia); and International Teaching Fellow, University College Cork (Ireland).

Abbi Flint is a HE Researcher and Educational Developer (UK); and Visiting Research Fellow in Student Engagement at Birmingham City University (UK).

Kathy Harrington is Principal Lecturer in Learning and Educational Development in HE, London Metropolitan University (UK), and Visiting Lecturer, The Tavistock and Portman NHS Foundation Trust, London (UK).

\section{REFERENCES}

Arthur, M. (2014). From research-led to research-based teaching. Research Fortnight 30 April.

Bovill, C. (2013). Students and staff co-creating curricula: An example of good practice in higher education? In Dunne, E. and Owen, D. (Eds.), The student engagement handbook: Practice in higher education (pp. 461-475). Bingley: Emerald.

Bryson, C. (Ed.) (2014). Understanding and developing student engagement. Abingdon: Routledge.

Cook-Sather, A., Bovill, C., \& Felten, P. (2014). Engaging students as partners in teaching and learning: $A$ guide for faculty. San Francisco: Jossey-Bass.

Crawford, K., Horsley, R., Hagyard, A., \& Derricot, D. (2015). Pedagogies of partnership: What works? York: HE Academy.

Dunne, E., \& Owen, D. (Eds.) (2013). The student engagement handbook: Practice in higher education. Bingley: Emerald.

Dunne, E., \& Zandstra, R. (2011). Students as change agents_New ways of engaging with learning and teaching in higher education. Bristol: A Joint University of Exeter/ESCalate/HE Academy Publication.

Evans, C., Muijs, D., \& Tomlinson, M. (2015). Engaged student learning: High-impact strategies to enhance student achievement. York: HE Academy.

Fanghanel, J., McGowan, S., Parker, P., McConnell, C., Potter, J., Locke, W., \& Healey, M. (2016). Defining and supporting the Scholarship of Teaching and Learning (SoTL): A sector-wide study. Literature review. York: HE Academy.

Felten, P., Bagg, J., Bumbry, M., Hill, J., Hornsby, K., Pratt, M., \& Weller, S. (2013). A call for expanding inclusive student engagement in SoTL. Teaching \& Learning Inquiry, 1(2), 63-74. 
Flint, A. (2015) Preface: Students and staff as partners in innovation and change. Journal of Educational Innovation, Partnership and Change, 1(1).

Flint, A., \& O'Hara, M. (2013) Communities of practice and the 'student voice:' Engaging with student representatives at the faculty level. Student Engagement and Experience Journal, 2(1).

Fung, D. (2015). UCL connected curriculum: A distinctive approach to research-based education. London: University College London Centre for Advancing Learning and Teaching.

Fung, D. (2016). Engaging students with research through a connected curriculum: An innovative institutional approach, CUR Quarterly (forthcoming).

Gärdebo, J., \& Wiggberg, M. (Eds.) (2012.) Students, the University's Unspent Resource: Revolutionising Higher Education through Active Student Participation. Report series 12, Division for Development of Teaching and Learning, Uppsala University.

Healey, M. (2016). Students as partners and change agents. Howden: Healey HE Consultants.

Healey, M, \& Addis, M. (2004). Use of peer and self-assessment to distribute group marks among individual team members: Ten years' experience. In Healey, M., and Roberts, J., (Eds.), Engaging students in active learning: Case studies in geography, environment and related disciplines (pp. 116-21). Cheltenham: University of Gloucestershire, Geography Discipline Network and School of Environment.

Healey, M., Bovill, C., \& Jenkins, A. (2015). Students as partners in learning. In Lea, J. (Ed.), Enhancing learning and teaching in higher education: Engaging with the dimensions of practice (pp.141-163). Maidenhead: Open University Press.

Healey, M., Flint, A., \& Harrington, K. (2014). Engagement through partnership: Students as partners in learning and teaching in higher education. York: HE Academy.

Healey, M., \& Jenkins, A. (2009). Developing undergraduate research and inquiry. York: HE Academy.

Healey, M., Mason O'Connor, K., \& Broadfoot, P. (2010). Reflecting on engaging students in the process and product of strategy development for learning, teaching and assessment: An institutional example. International Journal for Academic Development, 15(1), 19-32.

HE Academy. (2013). Students as partners change programme 2012-13: An overview of the programme, participating institutions and case studies. York: HE Academy.

HE Academy. (2015). Framework for student engagement through partnership. York: HE Academy.

Hodge, D. C., Nadler, M. K., Shore, C., \& Taylor, B. A. P. (2011). Institutionalizing large-scale curricular change: The top 25 project at Miami University. Change, 43(5), 28-35.

Kuh, G. D. (2009). High impact activities: What they are, why they work, who benefits. In Rust, C. (Ed.), Improving student learning through the curriculum (pp. 20-39). Oxford: Oxford Centre for Staff and Learning Development, Oxford Brookes University.

Jenkins, A., \& Healey, M. (2015). International perspectives on strategies to support faculty who teach students via research and inquiry. CUR Quarterly, 35(3), 31-37.

Lea, M. (2005). 'Communities of practice' in higher education. Useful heuristic or educational model? In Barton, D., \& Tusting, K. (Eds.), Beyond communities of practice: Language, power and social context (pp. 180-197). Cambridge: Cambridge University Press.

Little, S. (Ed.) (2011). Staff-student partnerships in higher education. London: Continuum.

Macquarie University (n.d.) Participation and community engagement (PACE).

Marquis, E., Puri, V., Wan, S., Ahmad, A., Goff, L., Knorr, K., Vassileva, I., \& Woo, J. (2016). Navigating the threshold of student-staff partnerships: A case study from an Ontario teaching and learning institute. International Journal for Academic Development, 21(1), 4-15.

Matthews, K., Marquis, E., \& Healey, M. (2016). Applying theories of communities of practice to reflect on international collaborative writing groups. In J. McDonald \& A. Cater-Steel (Eds.) Communities of practice_-Facilitating social learning in higher education. Dordrecht: Springer (in press).

MIIETL. (2015). MIIETL Strategic Plan 2014-19 (2015-16 update). Hamilton: McMaster University.

Neary, M. (2014). Student as producer: Research-engaged teaching frames university-wide curriculum development. CUR Quarterly, 35(2), 28-34.

NUS. (2012). A manifesto for partnership. London: National Union of Students.

Nygaard, C., Brand, S., Bartholomew, P., \& Millard, L. (Eds.) (2013). Student engagement-Identity, motivation and community. Faringdon: Libri.

Oxford Brookes University. (2013). Institutional Student ePioneer Partnerships.

Pauli, R., Raymond-Barker, B., \& Worrell, M. (2016). The impact of pedagogies of partnership on the student learning experience in UK higher education. York: HE Academy.

Sandover, S., Partridge, L., Dunne, E., \& Burkill, S. (2012). Undergraduate researchers change learning and teaching: A case study of two universities in Australia and the UK. CUR Quarterly, 33(1), 33-39. 
Siig Andersen, A., Wulf-Andersen, T., \& Heilesen, S. B. (2015). The evolution of the Roskilde Model, Denmark. CUR Quarterly, 36(2), 22-27.

Solomonides, I., Reid, A., \& Petocz, P. (Eds.) (2012). Engaging with learning in higher education. Faringdon: Libri.

sparqs (2012) Student Engagement Framework for Scotland.

Stoddard, I., Rieser, I., Andersson, S., \& Friman, E. (2012). Igniting a learning revolution: Student-run higher education for sustainable development. Solutions, 3(5), 34-9.

The Student Engagement Partnership (2014) The Principles of Student Engagement.

Thomas, L. (2012). Building student engagement and belonging in higher education at a time of change: Final report from the What Works? student retention \& success programme. York: HE Academy.

Tinto, V. (2003). Learning better together: The impact of learning communities on student success. In Promoting student success in college (pp. 1-8). Syracuse, NY: Syracuse University.

Werder, C., \& Otis, M. M. (Eds.) (2010). Engaging student voices in the study of teaching and learning. Virginia: Stylus.

\section{Student Response to "Students as Partners: Reflections on a Conceptual Model"1}

I think the paper is a clear display of what's currently playing out around the notion of students as partners in higher education. It's nice to read that this kind of partnering is happening in several places in the world and that universities are experimenting with possible forms of partnership.

I do have some questions:

- The authors state the fact that partnership in higher education is a powerful idea. They seem to suggest that it's so powerful because the implementation of which has the potential to transform higher education. They numerate forms of engaging students, but I'd like to see more details of why it has the potential to transform higher education.

- How do the students themselves experience peer-assisted learning? The authors seem to suggest that the concept of peer-assisted learning is a great way to engage students, and the benefits can be found in a paper by Clampett, et al. in this issue. I'd like to see these benefits to know why peer-assisted learning is a great way to engage students in higher education.

- I am wondering why students as partners in curriculum design is the least developed of the models presented in the piece. The authors seem to suggest that students are traditionally excluded from curriculum design. That is why, I think, students as partners in curriculum design is the hardest model to put into practice-because the current systems in universities are not equipped to do so.

I think partnering with students is a major step forward to make students more in control of their own education program. I also think it's still a bit top-down reasoned. Papers about engaging students as partners are written by researchers and applied by teachers. Has the question of what students need to get more involved in their own education be asked? 
I will take my own university (HAN University of Applied Sciences) as an example of a place where faculty staff and teachers are asking what students need to get more involved in their own education. At HAN University of Applied Sciences, faculty staff, teachers, and students are now experimenting with open curricula. The students themselves can decide what they do and don't want in their four years of higher education. Of course, there are some shared goals and it is supervised by teachers, but the students are in the lead. An open curriculum does ensure that students, accompanied by teachers, look at the content of their curriculum and, thus, determine their own goals.

Subject-based research, as a regular part of the curriculum, is something from which all students can benefit. During their education, students can experience what it is like to cooperate with professionals in a working environment. Physiotherapy students at HAN University of Applied Sciences are experiencing this right now. Students and teachers are working together in a so-called "practice house." They can examine and treat patients under the supervision of a teacher. Subjectbased research has been successful, and I think that all the students from the HAN (and other universities) could benefit from a similar program.

Lianne van Dam is an undergraduate psychology student at HAN University of Applied Sciences, the Netherlands.

NOTE

1. Note this commentary was written in relation to an earlier version of this article, which has since undergone significant clarifications and additions. authors, and copyright for the publication layout resides with the journal. These copyright holders have agreed that this article should be available on open access under a Creative Commons Attribution License 4.0 International (https://creativecommons.org/licenses/by/4.0). The only constraint on reproduction and distribution, and the only role for copyright in this domain, should be to give authors control over the integrity of their work and the right to be properly acknowledged and cited, and to cite Teaching \& Learning Inquiry as the original place of publication. Readers are free to share these materials-as long as appropriate credit is given, a link to the license is provided, and any changes are indicated. 